\title{
The Pentraxins, C-reactive Protein and Serum Amyloid P Component, Are Cleared and Catabolized by Hepatocytes In Vivo
}

\author{
Winston L. Hutchinson, George E. Noble, Philip N. Hawkins, and Mark B. Pepys \\ Immunological Medicine Unit, Department of Medicine, Royal Postgraduate Medical School, Hammersmith Hospital, \\ London W12 ONN, United Kingdom
}

\begin{abstract}
The cellular sites of clearance and degradation of the pentraxin plasma proteins, C-reactive protein, the classical acute phase reactant, and serum amyloid $P$ component (SAP), a universal constituent of amyloid deposits, were sought using the ligand ${ }^{125}$ I-tyramine cellobiose (TC) which is substantially retained within the cells in which catabolism takes place. Pentraxins labeled with ${ }^{125} \mathrm{I}-\mathrm{TC}$ showed the same in vitro and in vivo ligand binding and the same in vivo plasma $t_{1 / 2}$ as the directly iodinated proteins and the native unlabeled pentraxins, indicating that their mode of clearance was likely to be physiological. After intravenous injection into mice and rabbits of human C-reactive protein, human SAP, and mouse SAP, each labeled with ${ }^{125} \mathrm{I}-\mathrm{TC}$, most of the radioactivity remaining in the body at $24 \mathrm{~h}$ was located in hepatocytes. None was detected in other liver cells, and only traces were present in other viscera; the rest was in the carcass, representing intact pentraxins in the blood and extravascular compartment, and escaped label which had not yet been excreted. Hepatocytes are thus the single major site of pentraxin clearance and catabolism in vivo. This is consistent with the observation that SAP that has localized to amyloid deposits persists there and is not degraded. (J. Clin. Invest. 1994. 94:1390-1396.) Key words: acute phase proteins - amyloid $P$ component - clearance • C-reactive protein, hepatocyte
\end{abstract}

\section{Introduction}

The human pentraxin plasma proteins are C-reactive protein (CRP), ${ }^{1}$ the classical acute phase reactant, and serum amyloid $P$ component (SAP), a universal constituent of amyloid deposits (1). The three dimensional protein structure (2) and the complete glycostructure of SAP (3) have been characterized lately in detail, and the plasma turnover and distribution of both CRP and SAP in humans in health and disease have been reported $(4,5)$. However, their normal sites of clearance and catabolism have not been identified although this aspect of their

Address correspondence to Professor M. B. Pepys, Immunological Medicine Unit, Royal Postgraduate Medical School, Hammersmith Hospital, Du Cane Road, London W12 0NN, United Kingdom.

Received for publication 25 April 1994.

1. Abbreviations used in this paper: CRP, C-reactive protein; SAP, serum amyloid $\mathrm{P}$ component; TC, tyramine cellobiose.

J. Clin. Invest.

(c) The American Society for Clinical Investigation, Inc.

0021-9738/94/10/1390/07 $\$ 2.00$

Volume 94, October 1994, 1390-1396 metabolism is of fundamental and clinical interest for both proteins. For example, firstly, the rapid production and clearance of CRP have made it the marker of choice for monitoring of the acute phase response and it is widely used in clinical practice for determining the presence, extent, and activity of many infective and inflammatory disorders (6). Secondly, several lines of evidence suggest that SAP may participate in the persistence of amyloid deposits in vivo: SAP levels correlate with amyloidogenesis in experimental animal models (7-9), SAP is inherently proteinase resistant (10), and SAP in human amyloid deposits in vivo is neither degraded (11) nor modified ( 3 ). The route of catabolism of SAP may thus be important in amyloidogenesis.

CRP and SAP in the circulation are produced exclusively by hepatocytes and both turn over rapidly with plasma $t_{1 / 2}$ values of 19 and $24 \mathrm{~h}$, respectively $(4,5)$. In studies of normal subjects using ${ }^{123} \mathrm{I}$-labeled pentraxins, no tissue deposition or localization of either protein has been observed, nor any deposition of CRP in vivo in a variety of diseases (4). In contrast, SAP binds to all types of amyloid fibrils, and its in vivo deposition in amyloid is both readily demonstrable and exceptionally useful in clinical practice $(5,12,13)$. However, tracer studies with proteins directly labeled by oxidative iodination are not informative about the sites of clearance and catabolism because proteolysis is usually extremely rapid and the released iodotyrosine rapidly leaves the catabolizing cell and is excreted in the urine. We have therefore used pentraxins labeled with the nondegradable marker ${ }^{125}$ I-tyramine cellobiose (TC) in the trapped catabolism procedure (14) and found that hepatocytes are the major site of uptake and breakdown of these proteins.

\section{Methods}

Animals. Female CBA/Ca mice, 8-24 wk old (OLAC Ltd., Bicester, Oxon, United Kingdom), were used throughout and in each experiment were all of the same age. Amyloid A protein amyloidosis was induced in mice by daily subcutaneous injection of $0.5 \mathrm{ml} 10 \% \mathrm{wt} / \mathrm{vol}$ vitaminfree casein in $0.05 \mathrm{M} \mathrm{NaHCO}_{3}$ for $5 \mathrm{~d} / \mathrm{wk}$ for 4-6 wk (15). Individual female New Zealand White rabbits weighing $2.5 \mathrm{~kg}$ (Froxfield Farms UK Ltd., Froxfield, United Kingdom) were studied when normal and 24 and $48 \mathrm{~h}$ after induction of an acute phase response by subcutaneous injection of $2 \mathrm{ml}$ of $10 \% \mathrm{wt} / \mathrm{vol}$ vitamin-free casein in $0.05 \mathrm{M} \mathrm{NaHCO}_{3}$.

Pentraxins. Human and mouse SAP and human CRP were isolated and assayed essentially as described previously $(16,17)$, except that phosphoethanolamine immobilized on Sepharose was used as the calcium-dependent affinity ligand for the initial separation in each case (18). CRP was eluted with $1 \mathrm{mM}$ phosphocholine in $10 \mathrm{mM}$ Tris, 140

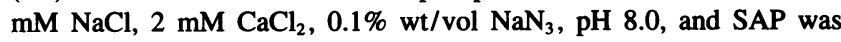
eluted using $10 \mathrm{mM}$ Tris, $140 \mathrm{mM} \mathrm{NaCl}, 0.1 \% \mathrm{wt} / \mathrm{vol} \mathrm{NaN} \mathrm{N}_{3}, \mathrm{pH} 8.0$. Mouse SAP was further purified by rebinding to phosphoethanolamineSepharose in Tris saline calcium buffer followed by elution with 10 $\mathrm{mM}$ Tris, $10 \mathrm{mM}$ EDTA, $140 \mathrm{mM} \mathrm{NaCl}, 0.1 \% \mathrm{wt} / \mathrm{vol} \mathrm{NaN}_{3}, \mathrm{pH} 8.0$. For each protein, the material isolated by affinity chromatography was concentrated by ultrafiltration and then gel filtered on Sephacryl S200 

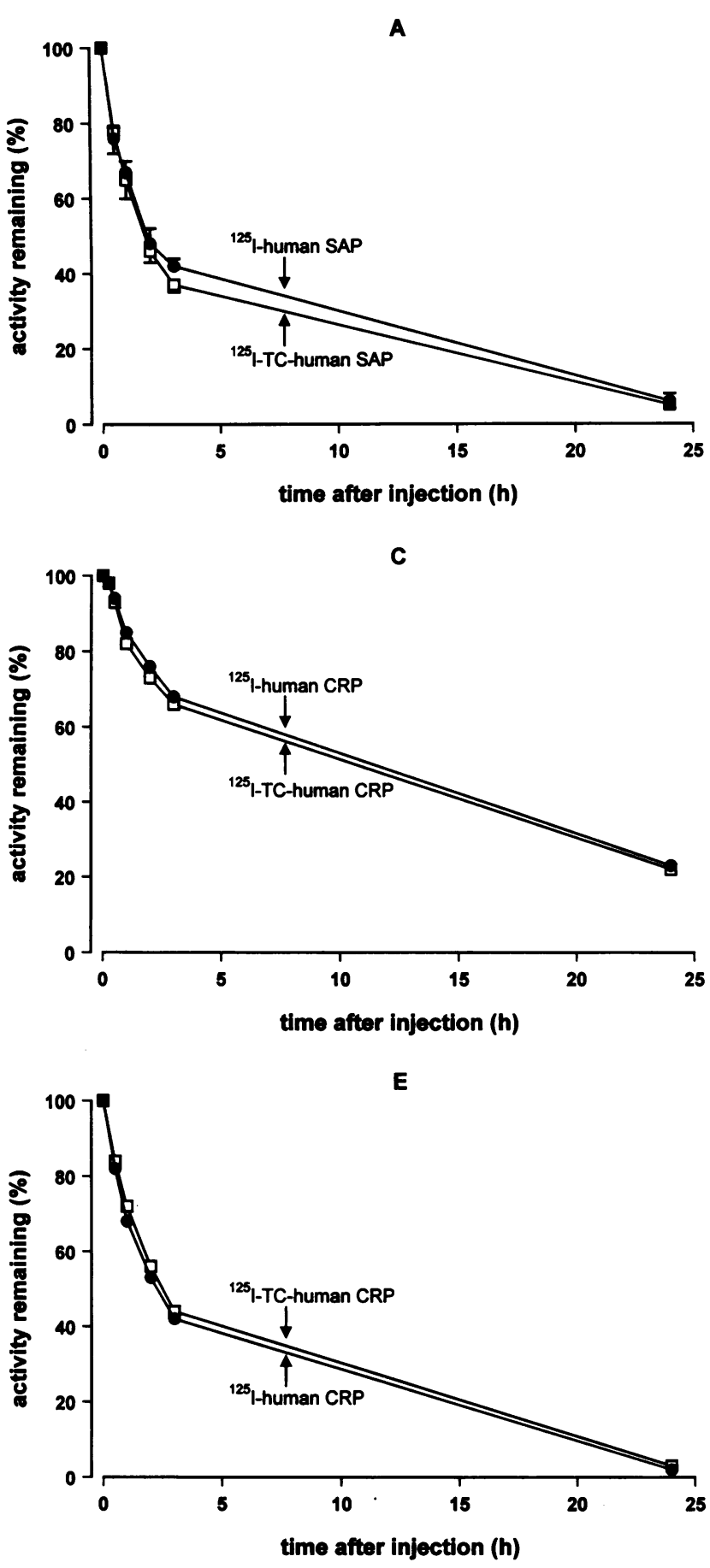

HR equilibrated with Tris saline EDTA buffer for SAP and Tris saline calcium buffer for CRP. The final products were all at least $99 \%$ pure by reduced SDS 8-18\% gradient PAGE analysis on Excel gels (Pharmacia Biotech, St. Albans, Herts, United Kingdom) loaded with at least $10 \mu \mathrm{g}$ of protein and stained with Coomassie blue.

Protein labeling. Direct oxidative iodination was performed using $\mathrm{N}$-bromosuccinimide as described before $(19,20) .{ }^{125} \mathrm{I}$-TC was synthesized and conjugated to proteins as reported previously (14) except that all the quantities of reagents used were greatly scaled down; tyramine $\mathrm{D}(+)$ cellobiose, cyanuric chloride, and 1,3,4,6,-tetrachloro $3 \alpha, 6 \alpha-$ diphenylglycouril (Iodogen) were from Sigma Chemical Co. (Poole Dorset, United Kingdom). For coupling the molar protein/TC ratio was 1:3. Functional integrity of each labeled pentraxin preparation was

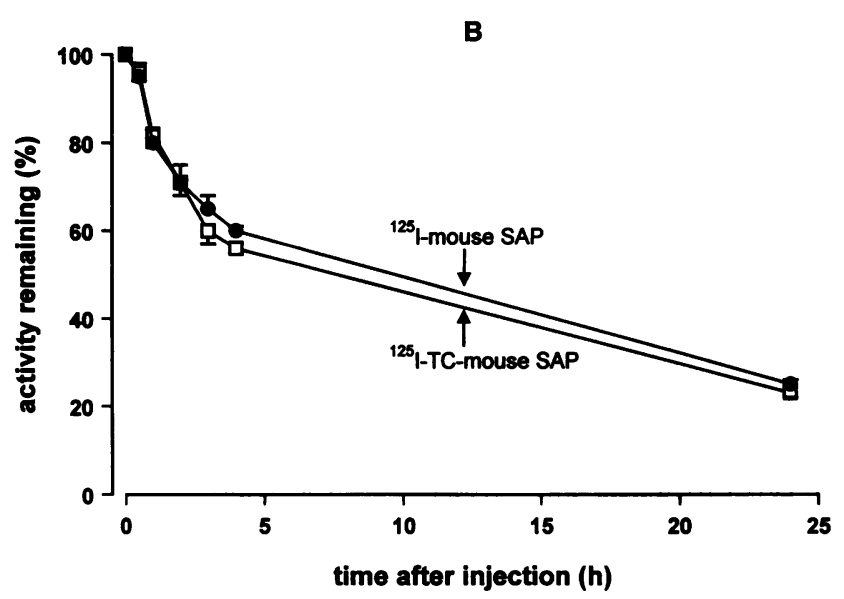

D

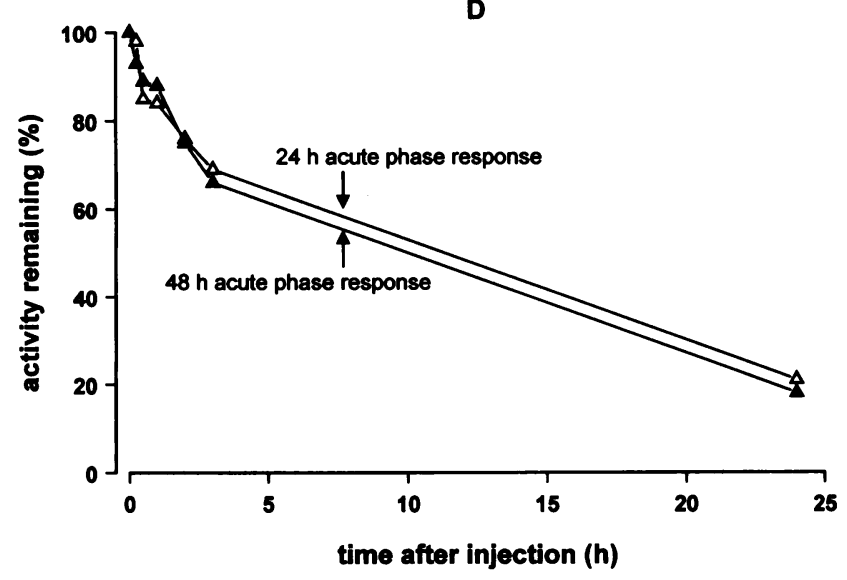

Figure 1. Clearance of circulating ${ }^{125} \mathrm{I}-\mathrm{TC}$-labeled pentraxins in normal animals, compared with clearance of the directly iodinated proteins. $(A)$ -, ${ }^{125} \mathrm{I}$ human SAP; and $\square,{ }^{125} \mathrm{I}-\mathrm{TC}$ human SAP in mice; each point represents the mean (SD) of three animals in each group. $(B) \bullet,{ }^{125} I$ mouse SAP; and $\square,{ }^{125}$ I-TC mouse SAP in mice; each point represents the mean (SD) of three animals in each group. $(C) \bullet,{ }^{125} \mathrm{I}$ human $\mathrm{CRP}$; and $\square,{ }^{125} \mathrm{I}-$ TC human CRP in individual rabbits. $(D){ }^{125} \mathrm{I}-\mathrm{TC}$ human CRP in individual rabbits at $24 \mathrm{~h}(\triangle)$ and $48 \mathrm{~h}(\triangle)$ after induction of an acute phase response. $(E) \bullet,{ }^{125} \mathrm{I}$ human CRP; and $\square,{ }^{125} \mathrm{I}$-TC human CRP in individual mice.

established by demonstration of its retained ability to undergo calciumdependent binding to phosphoethanolamine-Sepharose (18).

Blood clearance studies. Mice received 10-20 $\mu \mathrm{g}$ of labeled protein $(0.2-0.5 \mu \mathrm{Ci})$ intravenously via the lateral tail vein and were bled $\sim 100 \mu \mathrm{l}$ from the tail $2 \mathrm{~min}$ later to provide a zero time sample. Further tail vein bleeds were taken at intervals up to $24 \mathrm{~h}$ and individually weighed, and total radioactivity present corrected for the mass of blood present was expressed as a percentage of that present in the original sample. Rabbits received $20-50 \mu \mathrm{g}$ of labeled protein $(0.5-1.0 \mu \mathrm{Ci})$ via the left marginal ear vein and were bled from the right ear $5 \mathrm{~min}$ later for the zero time sample. Subsequent bleeds at intervals up to 24 $h$ were weighed and counted, and the percentage of remaining activity was calculated. 
Tissue localization. At the end of each clearance study the animals were killed, mice by cervical dislocation, and rabbits by intravenous injection of $60 \mathrm{mg}$ of sodium pentobarbitone, and the organs were individually removed, weighed, and counted. The eviscerated carcasses of the mice were also counted so that total remaining radioactivity could be calculated, but this was not technically possible with the rabbits.

Histology. Tissue was fixed immediately after death in $10 \%$ formaldehyde in $0.075 \mathrm{M}$ sodium phosphate buffer, $\mathrm{pH}$ 7.0. The cellular and tissue location of ${ }^{125} \mathrm{I}-\mathrm{TC}$ activity was determined by autoradiography using the dipping film method (21); $K_{2}$ liquid film emulsion (size A) was from Ilford Ltd. (Cheshire, United Kingdom). Morphological details were confirmed in serial sections stained with hematoxylin and eosin, and amyloid was identified by its pathognomonic green birefringence in polarized light after staining with Congo red (22).

\section{Results}

Integrity of ${ }^{125}$ I-TC-labeled pentraxins. Human SAP, mouse SAP, and human CRP that had been covalently labeled with ${ }^{125} \mathrm{I}-$ TC displayed precisely the same in vitro binding to immobilized phosphoethanolamine as directly iodinated pentraxins. Furthermore, the in vivo clearance of the ${ }^{125} \mathrm{I}$-TC pentraxins was the same as that of their directly labeled counterparts, both in mice and in rabbits (Fig. 1). Human SAP was cleared more rapidly than mouse SAP in normal mice, as reported previously (20, 23 ), and all proteins were cleared more rapidly in mice than in rabbits, but labeling with TC had no effect. Furthermore, human CRP was cleared at the same rate in normal rabbits and in animals mounting a major acute phase response. The clearance patterns observed here (Fig. 1) were essentially the same as reported previously $(20,23,24)$.

The capacity of TC-labeled SAP, both human and mouse, to localize in vivo to amyloid deposits in mice was identical to that of the directly iodinated proteins. There was the same accelerated clearance of labeled SAP from the plasma of amyloidotic mice compared with the normal controls (Fig. 2, $A$ and $B)$. There was also greater retention of ${ }^{125} \mathrm{I}-\mathrm{TC}$ activity in the liver and spleen (Fig. 3, $A$ and $B$ ), the sites of amyloid accumulation, than in normal animals. This enhanced organ localization corresponded to SAP deposition in the amyloid itself, demonstrated by autoradiography (Fig. 4), and was precisely as reported before with directly labeled SAP (23).

Labeling with ${ }^{125} \mathrm{I}-\mathrm{TC}$ thus did not alter the in vivo behavior or handling of the pentraxins compared with the directly labeled proteins, and their central functional property of ligand-binding, both in vitro and in vivo, was retained. We have reported previously that the behavior of pentraxins labeled by direct oxidative iodination, as described here, is identical to that of the native unaltered proteins $(4,11)$, and the ${ }^{125} \mathrm{I}$-TC-labeled pentraxins were therefore suitable tracers for identification of the physiological cellular sites of pentraxin catabolism in vivo.

Distribution of activity from ${ }^{125}$ I-TC SAP in normal mice. Despite marked trapping and retention of radioactivity after injection of SAP labeled with ${ }^{125} \mathrm{I}-\mathrm{TC}$, compared with directly iodinated SAP, some of the injected dose had been excreted by $24 \mathrm{~h}$. Most of the amount remaining was located in the liver with only traces in any of the other viscera (Fig. 3). Activity in the carcass reflects both intact protein in the blood and extravascular compartment and labeled breakdown products that have escaped from the cellular site of catabolism but have not yet been excreted. Slightly higher activity in the intestines than in the other nonhepatic organs suggests that the tracer may be excreted via the bowel. In animals receiving human SAP, there
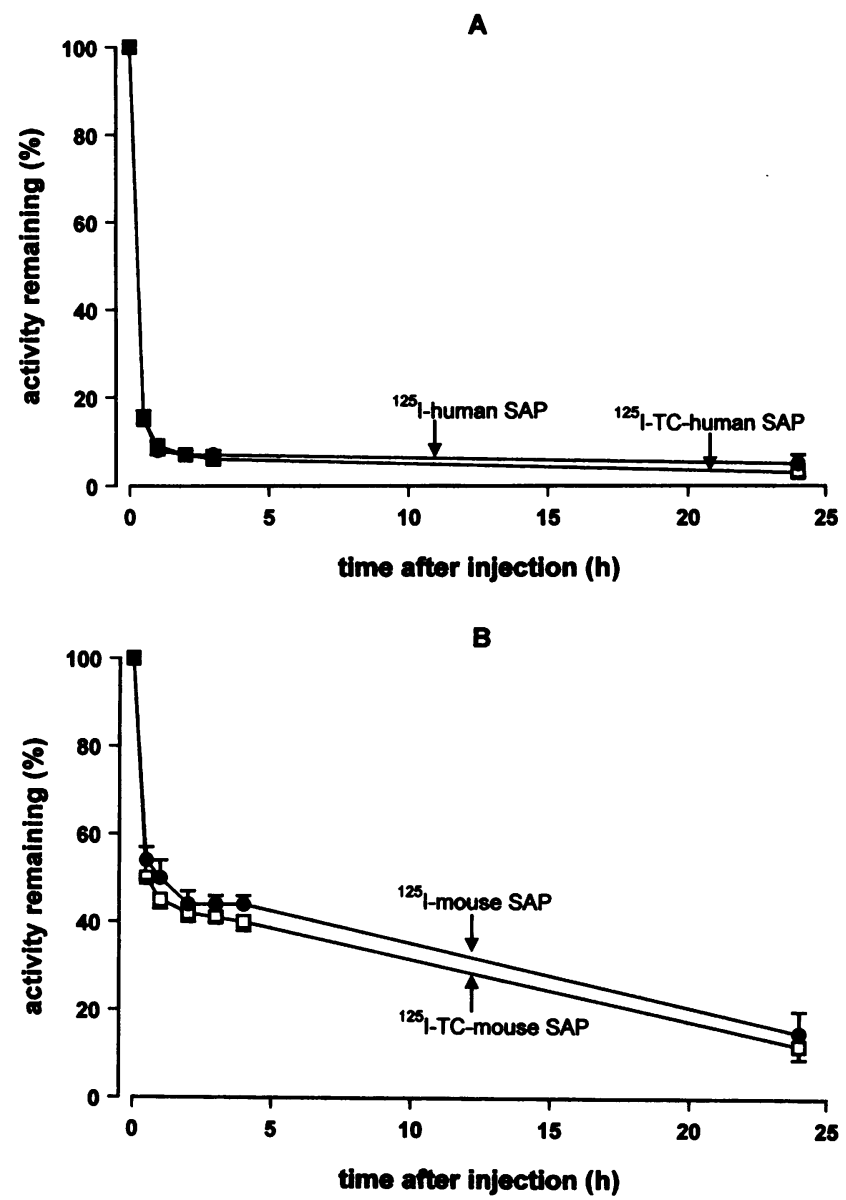

Figure 2. Clearance of circulating ${ }^{125} \mathrm{I}-\mathrm{TC}-$ labeled SAP in amyloidotic mice compared with clearance of directly iodinated SAP. $(A) \bullet,{ }^{125} I$ human SAP; and $\square,{ }^{125} \mathrm{I}-\mathrm{TC}$ human SAP. $(B) \bullet,{ }^{125} \mathrm{I}$ mouse SAP; and $\square,{ }^{125} \mathrm{I}$-TC mouse SAP. Each point represents the mean (SD) of three animals in each group.

was more activity in the liver and less in the carcass than in animals receiving mouse SAP. This corresponds to the more rapid clearance of the xenogeneic compared with the isogeneic pentraxin (Fig. 1).

Distribution of activity from ${ }^{125}$ I-TC SAP in amyloidotic mice. The results in amyloidotic mice were similar to those in normal animals except that there was more activity in the liver and spleen, the sites of amyloid deposition, reflecting binding of intact SAP molecules to amyloid deposits as well as trapped catabolism (Fig. 3). There was also correspondingly less activity remaining in the carcass, reflecting the more rapid plasma clearance (Figs. 1 and 2).

Distribution of activity from ${ }^{125}$ I-TC human CRP in mice. At $24 \mathrm{~h}$ after injection, $70 \%$ of the retained activity was in the liver, and only traces were present in other viscera. A small proportion remained in the carcass, representing undegraded protein and unexcreted breakdown products in the blood and extravascular compartment (Table I).

Distribution of ${ }^{125}$ I-TC human CRP in rabbits. The organ distribution of activity in rabbits which received ${ }^{125} \mathrm{I}-\mathrm{TC}$ human CRP was essentially the same as in mice injected with ${ }^{125}$ I-TClabeled pentraxins, although the proportions of total retained activity could not be calculated because the carcass was not 


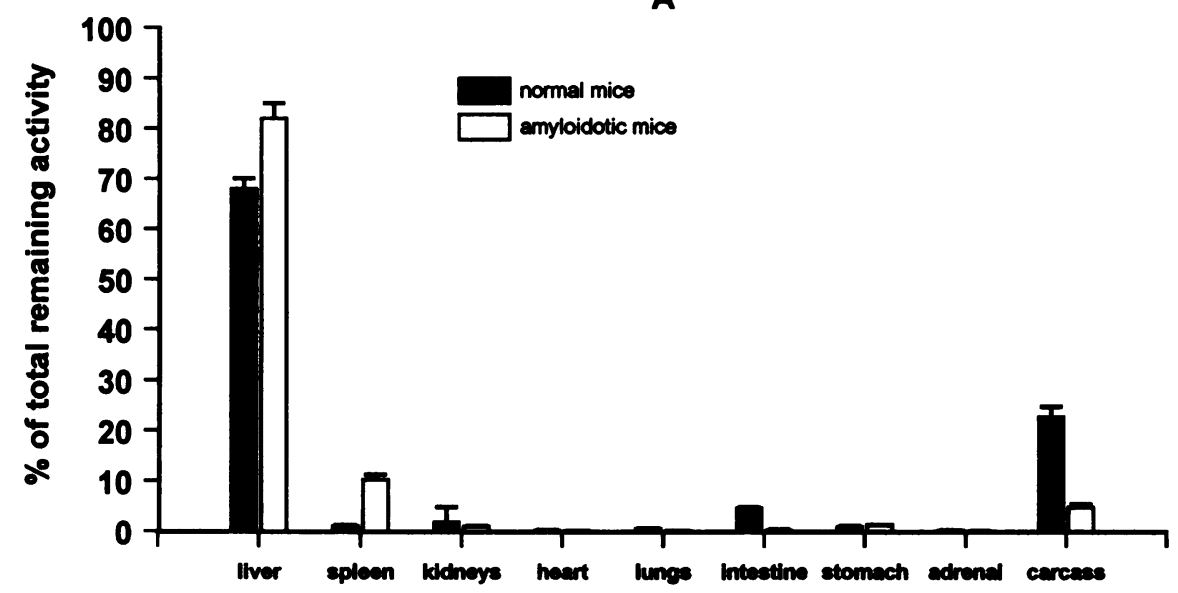

B

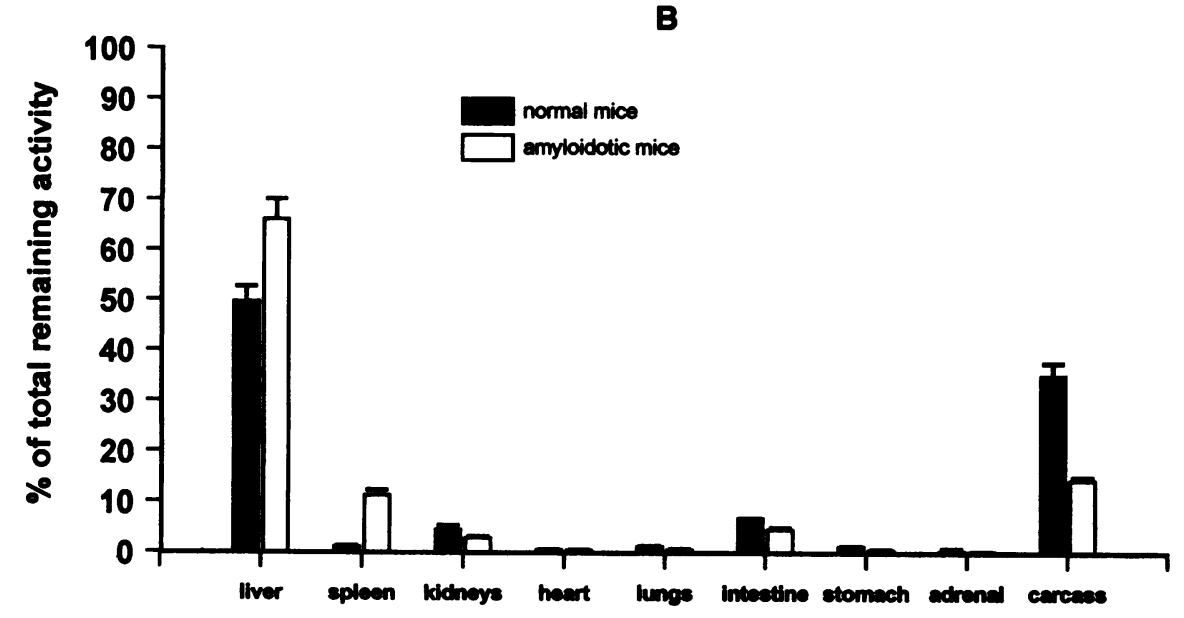

Figure 3. Organ distribution of radioactivity from ${ }^{125} \mathrm{I}$-TC-labeled SAP at $24 \mathrm{~h}$ after intravenous injection in mice. Each bar represents the mean (SD) of three animals in each group. (A) Human SAP. (B) Mouse SAP.

counted. Most was present in the liver, and there were only trace quantities in the other viscera (Table II). This pattern was unaffected by the presence of an intercurrent acute phase response.

Cellular location of pentraxin catabolism. Autoradiographs of histological sections of the livers of normal rabbits and mice which had received ${ }^{125} \mathrm{I}$-TC-labeled pentraxins showed activity only in hepatocytes. In the rabbits injected with ${ }^{125} \mathrm{I}-\mathrm{TC}$ human CRP, the labeled cells were all in zone 1 , close to the portal tracts, but in mice receiving mouse SAP or human pentraxins there was no zonal localization (Fig. 4). No activity was associated with Kupffer cells, nor was any signal detectable in autoradiographs of other tissues. In amyloidotic mice which had been injected with ${ }^{125} \mathrm{I}-\mathrm{TC}$ SAP, tracer was present in hepatic and splenic amyloid deposits as well as in hepatocytes (Fig. 4).

\section{Discussion}

The trapped catabolism method for identifying the cellular site of protein breakdown uses a covalent label that cannot be degraded and that is retained within the cells responsible for its cleavage from the protein. Tyramine cellobiose is currently the best available material for this purpose (14). Cellobiose is not metabolized by mammalian cells and is trapped within lysosomes, while the tyramine conjugated to it provides a convenient structure for radioiodination and for covalent coupling to protein. The radioactive degradation products of catabolism of ${ }^{125} \mathrm{I}-\mathrm{TC}$-protein conjugates are thus retained within the catabolizing cells and provide a cumulative index of tissue uptake. Such retention is, of course, not absolute, and we elected to monitor distribution at $24 \mathrm{~h}$ after injection of tracer rather than at later times when, despite catabolism of a greater proportion of the conjugate, there would also be more leakage of product.

A critical criterion for physiological interpretation of the results is that labeling with ${ }^{125} \mathrm{I}-\mathrm{TC}$ should not affect the properties, behavior, or handling of the protein. We therefore established that our ${ }^{125} \mathrm{I}-\mathrm{TC}$ pentraxins were the same as their directly iodinated counterparts with respect to in vitro ligand binding and in vivo handling. Furthermore, we showed that the ${ }^{125} \mathrm{I}-$ TC SAP preparations retained in full the capacity of directly iodinated and indeed native unlabeled SAP to localize and bind to amyloid deposits in vivo. Pentraxins oxidatively iodinated using $N$-bromosuccinimide, as described here, are indistinguishable from the native proteins with respect to ligand binding and in vivo clearance $(4,11)$. We are therefore confident that the distribution and catabolism of the ${ }^{125} \mathrm{I}-\mathrm{TC}$ pentraxins accurately reflect the physiological handling of native pentraxins.

The results obtained with mouse SAP in the mouse and with human pentraxins in mice and rabbits were the same. There was major uptake in the liver and very little indeed in any other visceral organs. The proportion retained in the liver was highest when the protein in question was most rapidly cleared from the 

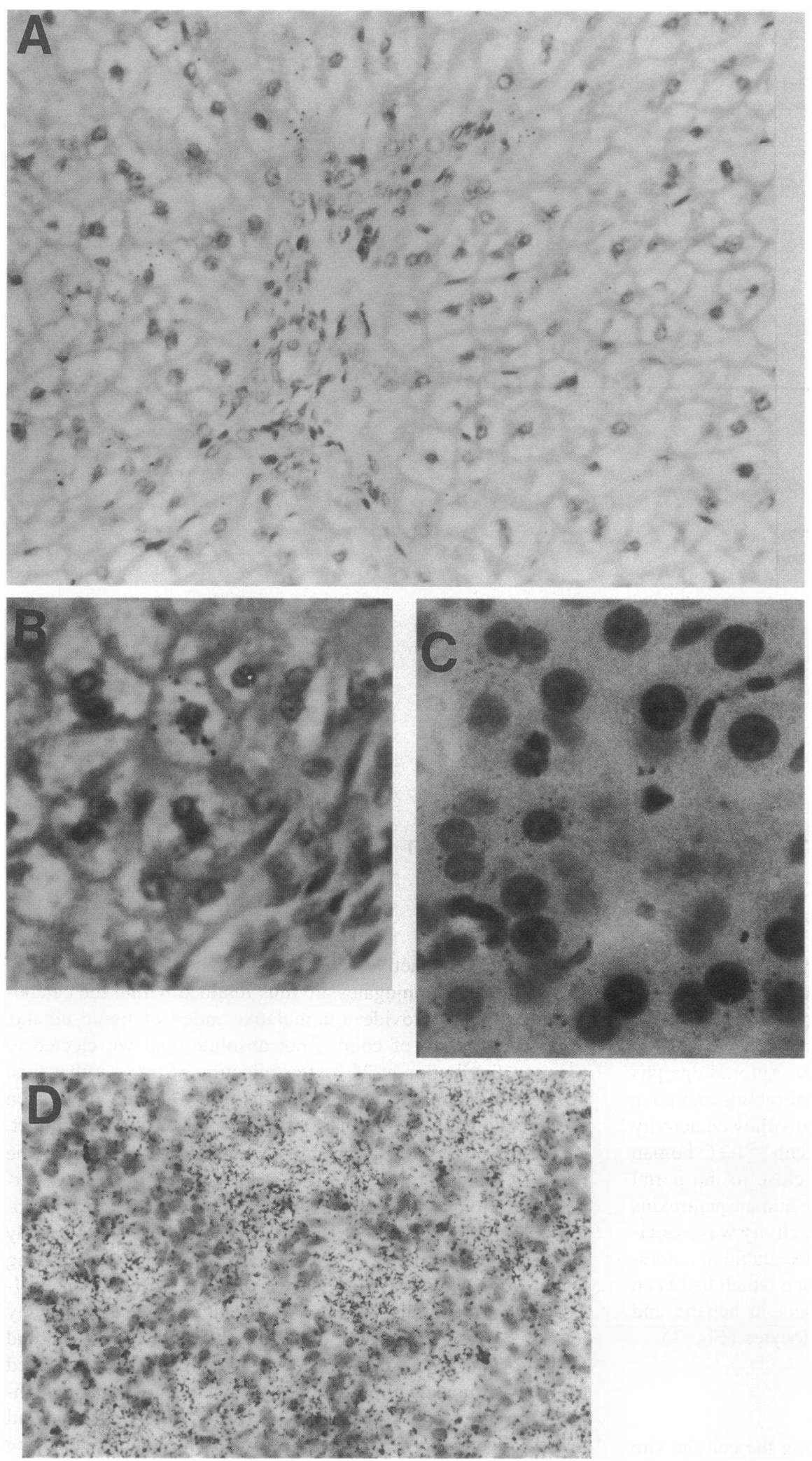

plasma, and there was correspondingly less in the carcass. The animals were killed by cervical dislocation or terminal anesthesia and were not exsanguinated. Activity in the carcass therefore includes both residual intact labeled pentraxin molecules in the blood and extravascular fluid and "escaped" products of catab-
Figure 4. Autoradiographs of tissue sections from animals that had received ${ }^{125} \mathrm{I}-\mathrm{TC}-\mathrm{la}$ beled pentraxins $24 \mathrm{~h}$ previously. $(A)$ Human CRP in normal rabbit liver, low power view $(\times 200)$ showing grains in individual hepatocytes close to a portal tract, and $(B)$ high power $(\times 300)$ showing grains in a cell with typical morphology surrounded by three characteristically binucleate hepatocytes. $(C)$ Mouse SAP in normal mouse liver, high power view $(\times 500)$ showing grains in individual hepatocytes in midlobular zone. $(D)$ Mouse SAP in an amyloid-laden spleen, low power view $(\times 200)$ showing grains heavily concentrated over the pale, unstained, acellular amyloid deposits.

olism which have not yet been excreted. The somewhat higher counts in the intestines than elsewhere, apart from the liver itself, are compatible with fecal excretion of label after protein catabolism in the liver.

Although the liver is an important site for catabolism of 
Table I. Organ Distribution of Activity from ${ }^{125}$ I-TC Human CRP in the Mouse

\begin{tabular}{lc}
\hline Organ & $\begin{array}{c}\text { Percentage of total activity } \\
\text { remaining at } 24 \mathrm{~h}\end{array}$ \\
\hline Liver & 70.4 \\
Spleen & 1.0 \\
Kidneys & 3.3 \\
Heart & 0.5 \\
Lungs & 0.5 \\
Intestines & 5.9 \\
Stomach & 0.4 \\
Adrenals & 0.2 \\
Carcass & 17.8 \\
\hline
\end{tabular}

Data are from a single animal.

most of the other plasma proteins previously studied by the TC trapped catabolism method, many of them are also broken down significantly in other sites: transferrin in the bone marrow, lungs, and spleen (25); apoproteins of high density lipoprotein in the kidneys, ovaries, and adrenals $(26,27)$; low density lipoprotein in the adrenals and spleen $(28,29)$; transthyretin in muscle, skin, kidneys, adipose tissue, testes, and gut (30). Apolipoprotein $\mathrm{AI}$ is predominantly cleared and catabolized in the kidneys (27), and this is the exclusive site for lysozyme (31), though this is a special case because of its low molecular weight. In contrast, the liver is clearly the single main site of uptake and catabolism of both CRP and SAP, and histological autoradiography indicated that hepatocytes rather than Kupffer cells are responsible. In the rabbits receiving human CRP, catabolism was confined to occasional cells in zone 1 surrounding the portal tracts, but in mice receiving mouse SAP or human pentraxins cells scattered throughout the lobule were labeled. We do not know whether the cells involved are a specialized subset of hepatocytes or are merely those that have taken up the labeled proteins by chance. The present findings do not preclude the possibility that small amounts of pentraxins may also be catabolized in other cell types. Indeed uptake of ${ }^{125}$ I-TC SAP in the adrenal glands expressed per mass of tissue approached that in the liver, although the absolute quantity was very small and its physiological significance, if any, is not clear.

SAP and CRP are both very resistant to proteolytic degradation $(10,32)$, and in amyloidosis, SAP, which has localized to the deposits as a result of its calcium-dependent binding to the amyloid fibrils, persists there for prolonged periods without being catabolized or altered in any way $(3,11)$. This phenomenon, which may be important in the persistence of amyloid deposits in vivo $(2,33)$, is entirely compatible with the present demonstration that hepatocytes are the only cells in which significant catabolism of pentraxins occurs. Of interest, the liver is usually involved late in systemic amyloidosis, even when the precursor of the fibril protein is of liver origin, raising the possibility that proximity to the cells responsible for SAP catabolism may alter the dynamic equilibrium of the SAP-amyloid fibril interaction so as to reduce amyloid deposition or persistence. However, even if this speculation is correct, it does not always apply since many patients with either acquired or hereditary amyloidosis have massive hepatic amyloid deposition
Table II. Organ Distribution of Activity from ${ }^{125}$ I-TC Human CRP in the Rabbit

\begin{tabular}{lccc}
\hline & \multicolumn{3}{c}{ Percentage of injected dose remaining at $24 \mathrm{~h}$} \\
\cline { 2 - 4 } \multicolumn{1}{c}{ Organ } & Normal rabbit & $\begin{array}{c}24 \mathrm{~h} \text { acute phase } \\
\text { response }\end{array}$ & $\begin{array}{c}48 \mathrm{~h} \text { acute phase } \\
\text { response }\end{array}$ \\
\hline Liver & 18.0 & 20.0 & 21.0 \\
Spleen & 0.3 & 0.3 & 0.3 \\
Kidneys & 1.6 & 1.6 & 1.0 \\
Heart & 0.3 & 0.3 & 0.1 \\
Lungs & 0.6 & 0.5 & 0.2 \\
Intestines & 4.0 & 3.0 & 2.0 \\
Stomach & 0.5 & 0.4 & 0.1 \\
\hline
\end{tabular}

Data are from individual animals. The results are expressed as a percentage of injected dose rather than as a percentage of activity remaining at $24 \mathrm{~h}$ after injection because it was not technically possible to count the whole rabbit carcasses.

despite apparently normal catabolism of circulating SAP $(11,34-36)$.

The mechanisms responsible for recognition and uptake of circulating pentraxins destined for degradation by the hepatocytes are not known. Human CRP is not glycosylated, and a protein recognition mechanism must therefore be involved. Human and mouse SAP are both glycosylated, and we have shown lately that desialylation of human SAP causes it to be very rapidly cleared in the liver via the asialoglycoprotein receptor, both in mice and humans (3). However, this may not be the normal physiological pathway for SAP clearance because complete blockade of the asialoglycoprotein receptor in mice in vivo did not retard the clearance of normally sialylated SAP (3). Whatever the recognition and uptake mechanisms may be, they evidently have high capacity. The plasma $t_{1 / 2}$ of human CRP in humans is independent of the circulating CRP level (4), and in the present study the plasma clearance and liver uptake of human CRP in rabbits were unaffected by an intercurrent acute phase response of rabbit CRP. Similarly, our previous studies indicated that the plasma clearance of mouse SAP, which unlike human SAP (37) is a major acute phase protein (38), is also independent of the concentration in the circulation (39).

\section{Acknowledgments}

We thank Prof. M. Saraiva for suggesting the trapped catabolism method and Ms. Beth Sontrop for expert preparation of the manuscript.

This work was supported by Medical Research Council Programme Grant G7900510.

\section{References}

1. Pepys, M. B., and M. L. Baltz. 1983. Acute phase proteins with special reference to C-reactive protein and related proteins (pentaxins) and serum amyloid A protein. Adv. Immunol. 34:141-212.

2. Emsley, J., H. E. White, B. P. O'Hara, G. Oliva, N. Srinivasan, I. J. Tickle, T. L. Blundell, M. B. Pepys, and S. P. Wood. 1994. Structure of pentameric human serum amyloid P component. Nature (Lond.). 367:338-345.

3. Pepys, M. B., T. W. Rademacher, S. Amatayakul-Chantler, P. Williams, G. E. Noble, W. L. Hutchinson, P. N. Hawkins, S. R. Nelson, J. R. Gallimore, J. Herbert, et al. 1994. Human serum amyloid P component is an invariant constit- 
uent of amyloid deposits and has a uniquely homogeneous glycostructure. Proc. Natl. Acad. Sci. USA. 91:5602-5606.

4. Vigushin, D. M., M. B. Pepys, and P. N. Hawkins. 1993. Metabolic and scintigraphic studies of radioiodinated human C-reactive protein in health and disease. J. Clin. Invest. 91:1351-1357.

5. Hawkins, P. N., J. P. Lavender, and M. B. Pepys. 1990. Evaluation of systemic amyloidosis by scintigraphy with ${ }^{123}$ I-labeled serum amyloid $\mathrm{P}$ component. N. Engl. J. Med. 323:508-513.

6. Pepys, M. B. 1987. The acute phase response and C-reactive protein. In Oxford Textbook of Medicine. 2nd ed. D. J. Weatherall, J. G. G. Ledingham, and D. A. Warrell, editors. Oxford University Press, Oxford. 9.157-9.164.

7. Baltz, M. L., K. Gomer, A. J. S. Davies, D. J. Evans, G. G. B. Klaus, and M. B. Pepys. 1980. Differences in the acute phase responses of serum amyloid $\mathrm{P}$ component (SAP) and $\mathrm{C} 3$ to injections of casein or bovine serum albumin in amyloid-susceptible and resistant mouse strains. Clin. Exp. Immunol. 39:355360 .

8. Snel, F., T. A. Niewold, M. L. Baltz, P. R. Hol, A. M. van Ederen, M. B. Pepys, and E. Gruys. 1989. Experimental amyloidosis in the hamster: correlation between hamster female protein levels and amyloid deposition. Clin. Exp. Immunol. 76:296-300.

9. Coe, J. E., and M. J. Ross. 1990. Amyloidosis and female protein in the Syrian hamster. J. Exp. Med. 171:1257-1267.

10. Kinoshita, C. M., A. T. Gewurz, J. N. Siegel, S.-C. Ying, T. E. Hugli, J. E. Coe, R. K. Gupta, R. Huckman, and H. Gewurz. 1992. A protease-sensitive site in the proposed $\mathrm{Ca}^{2+}$-binding region of human serum amyloid $\mathrm{P}$ component and other pentraxins. Protein Science. I:700-709.

11. Hawkins, P. N., R. Wootton, and M. B. Pepys. 1990. Metabolic studie of radioiodinated serum amyloid $\mathrm{P}$ component in normal subjects and patients with systemic amyloidosis. J. Clin. Invest. 86:1862-1869.

12. Hawkins, P. N., S. Richardson, J. E. MacSweeney, A. D. King, D. M Vigushin, J. P. Lavender, and M. B. Pepys. 1993. Scintigraphic quantification and serial monitoring of human visceral amyloid deposits provide evidence for turnover and regression. Q. J. Med. 86:365-374.

13. Hawkins, P. N., S. Richardson, D. M. Vigushin, J. David, C. R. Kelsey, R. E. S. Gray, M. A. Hall, P. Woo, J. P. Lavender, and M. B. Pepys. 1993 Serum amyloid $P$ component scintigraphy and turnover studies for diagnosis and quantitative monitoring of AA amyloidosis in juvenile rheumatoid arthritis Arthritis Rheum. 36:842-851.

14. Pittman, R. C., T. E. Carew, C. K. Glass, S. R. Green, C. R. J. Taylor, and A. D. Attie. 1983. A radioiodinated, intracellularly trapped ligand for determining the sites of plasma protein degradation. Biochem. J. 212:791-800.

15. Janigan, D. T. 1965 . Experimental amyloidosis. Studies with a modified casein method, casein hydrolysate and gelatin. Am. J. Pathol. 47:159-171.

16. de Beer, F. C., and M. B. Pepys. 1982. Isolation of human C-reactive protein and serum amyloid P component. J. Immunol. Methods. 50:17-31.

17. Pepys, M. B. 1979. Isolation of serum amyloid $\mathbf{P}$ component (protein $\mathrm{SAP}$ ) in the mouse. Immunology. 37:637-641.

18. Hawkins, P. N., G. A. Tennent, P. Woo, and M. B. Pepys. 1991. Studies in vivo and in vitro of serum amyloid $P$ component in normals and in a patient with AA amyloidosis. Clin. Exp. Immunol. 84:308-316.

19. Reay, P. 1982. Use of $N$-bromosuccinimide for the iodination of proteins for radioimmunoassay. Ann. Clin. Biochem. 19:129-133.

20. Hawkins, P. N., M. J. Myers, A. A. Epenetos, D. Caspi, and M. B. Pepys. 1988. Specific localization and imaging of amyloid deposits in vivo using ${ }^{123} \mathrm{I}$ labeled serum amyloid P component. J. Exp. Med. 167:903-913.

21. Flitney, E. 1990. Autoradiography. In Theory and Practice of Histologica Techniques. 3rd ed. J. D. Bancroft, A. Stevens, and D. R. Turner, editors. Churchill Livingstone, Edinburgh. 645-665.
22. Puchtler, H., F. Sweat, and M. Levine. 1962. On the binding of Congo red by amyloid. J. Histochem. Cytochem. 10:355-364.

23. Baltz, M. L., D. Caspi, D. J. Evans, I. F. Rowe, C. R. K. Hind, and M. B. Pepys. 1986. Circulating serum amyloid P component is the precursor of amyloid $\mathrm{P}$ component in tissue amyloid deposits. Clin. Exp. Immunol. 66:691700 .

24. Rowe, I. F., M. L. Baltz, A. K. Soutar, and M. B. Pepys. 1984. In vivo turnover studies of $\mathrm{C}$-reactive protein and lipoprotein in the rabbit. Clin. Exp. Immunol. 58:245-252.

25. Hu, W. L., P. A. Chindemi, and E. Regoeczi. 1992. In vivo behaviour of rat transferrin bearing a hybrid glycan and its interaction with macrophages. Biochem. Cell Biol. 70:636-642.

26. Goldberg, I. J., W. S. Blaner, T. M. Vanni, M. Moukides, and R. Ramakrishnan. 1990. Role of lipoprotein lipase in the regulation of high density lipoprotein apolipoprotein metabolism. Studies in normal and lipoprotein lipase-inhibited monkeys. J. Clin. Invest. 86:463-473.

27. Glass, C. K., R. C. Pittman, G. A. Keller, and D. Steinberg. 1983. Tissue sites of degradation of apoprotein A-I in the rat. J. Biol. Chem. 258:7161-7167.

28. Moerlein, S. M., K. B. Dalal, S. N. Ebbe, Y. Yano, and T. F. Budinger. 1988. Residualizing and non-residualizing analogues of low-density lipoprotein as iodine-123 radiopharmaceuticals for imaging LDL catabolism. Int. J. Radiat. Appl. Instrum. Part B. 15:141-149.

29. Gustafson, S., C. Vahlquist, L. Sjoblom, A. Eklund, and A. Vahlquist. 1990. Metabolism of very low density lipoproteins in rats with isotretinoin (13 cis retinoic acid)-induced hyperlipidemia. J. Lipid Res. 31:183-190.

30. Makover, A., H. Moriwaki, R. Ramakrishnan, M. J. M. Saraiva, W. S Blaner, and D. S. Goodman. 1988. Plasma transthyretin. Tissue sites of degradation and turnover in the rat. J. Biol. Chem. 263:8598-8603.

31. Hysing, J., and H. Tolleshaug. 1986. Quantitative aspects of the uptake and degradation of lysozyme in the rat kidney in vivo. Biochim. Biophys. Acta. 887:42-50.

32. Kinoshita, C. M., S.-C. Ying, T. E. Hugli, J. N. Siegel, L. A. Potempa, H. Jiang, R. A. Houghten, and H. Gewurz. 1989. Elucidation of a proteasesensitive site involved in the binding of calcium to C-reactive protein. Biochemis try. 28:9840-9848.

33. Hind, C. R. K., P. M. Collins, D. Caspi, M. L. Baltz, and M. B. Pepys. 1984. Specific chemical dissociation of fibrillar and non-fibrillar components of amyloid deposits. Lancet. ii:376-378.

34. Pepys, M. B. 1994. Amyloidosis. In Samter's Immunological Diseases 5th ed. M. M. Frank, K. F. Austen, H. N. Claman, and E. R. Unanue, editors Little, Brown and Company, Boston. 637-655.

35. Soutar, A. K., P. N. Hawkins, D. M. Vigushin, G. A. Tennent, S. E. Booth, T. Hutton, O. Nguyen, N. F. Totty, T. G. Feest, J. J. Hsuan, and M. B. Pepys. 1992. Apolipoprotein AI mutation Arg-60 causes autosomal dominan amyloidosis. Proc. Natl. Acad. Sci. USA. 89:7389-7393.

36. Pepys, M. B., P. N. Hawkins, D. R. Booth, D. M. Vigushin, G. A. Tennent, A. K. Soutar, N. Totty, O. Nguyen, C. C. F. Blake, C. J. Terry, et al. 1993. Human lysozyme gene mutations cause hereditary systemic amyloidosis. Nature (Lond.). 362:553-557.

37. Pepys, M. B., A. C. Dash, R. E. Markham, H. C. Thomas, B. D. Williams, and A. Petrie. 1978. Comparative clinical study of protein SAP (amyloid P component) and C-reactive protein in serum. Clin. Exp. Immunol. 32:119-124.

38. Pepys, M. B., M. Baltz, K. Gomer, A. J. S. Davies, and M. Doenhoff 1979. Serum amyloid $P$ component is an acute phase reactant in the mouse Nature (Lond.). 278:259-261.

39. Baltz, M. L., R. F. Dyck, and M. B. Pepys. 1985. Studies of the in vivo synthesis and catabolism of serum amyloid P component (SAP) in the mouse. Clin. Exp. Immunol. 59:235-242. 